\title{
"I start learning English through speaking": Social agency demand and inter-school readiness for Indonesian young English learners
}

\author{
Sri Setyarini*, Bachrudin Musthafa, and Ahmad Bukhori Muslim \\ Department of English Education, Faculty of Language and Literature Education, Universitas Pendidikan \\ Indonesia, Jl. Dr. Setiabudhi 229, Bandung, West Java, Indonesia
}

\begin{tabular}{|c|c|}
\hline \multirow{2}{*}{\multicolumn{2}{|c|}{$\begin{array}{l}\text { ABSTRACT } \\
\text { Preserving Indonesian as a national identity and institutional readiness to perform the national } \\
\text { curriculum } 2013 \text { instruction has become a critical factor in the exclusion of English as a } \\
\text { compulsory subject at the elementary school level. This leaves rooms for teachers' confusion and } \\
\text { creativity, leading to various practices at different school clusters, depending on parental demands } \\
\text { and school readiness. This study thus tries to cast light on the social agency demand and inter- } \\
\text { school readiness for young learners in the Indonesian EFL pedagogical contexts. This } \\
\text { instrumental case study portrays the practices of English language teaching at three clusters of } \\
\text { Indonesian primary schools; local, national, and independent, as well as responses of parents and } \\
\text { students to these practices. Involving 4-6 grade students and English teachers of six primary } \\
\text { schools, the data were garnered through classroom observation, interviews, and document } \\
\text { analysis. The findings revealed that although teaching English to young learners is somehow } \\
\text { communicative and fun, it more emphasises literacy skills (reading, writing, and grammar), } \\
\text { particularly at local schools as the majority cluster across the country. Since English is a non- } \\
\text { phonetic language, this literacy-focused practice is rather contradictory to what parents as social } \\
\text { agencies expect, that is, to develop their children's English oral proficiency. The study also offers } \\
\text { ways by which teachers and schools can accommodate this social agency's needs for speaking } \\
\text { skills by focusing more on student-centred and oral English proficiency activities and assessment. } \\
\text { Keywords: English for young learners; interschool readiness; social agency demand; speaking } \\
\text { skill }\end{array}$}} \\
\hline & \\
\hline & \\
\hline \multicolumn{2}{|c|}{$\begin{array}{l}\text { How to cite (in APA style): } \\
\text { Setyarini, S., Musthafa, B., \& Muslim, A. B. (2020). “I start learning English through } \\
\text { speaking": Social agency demand and inter-school readiness for Indonesian young } \\
\text { English learners. Indonesian Journal of Applied Linguistics, 10(1), 218-225. } \\
\text { https://doi.org/10.17509/ijal.v10i1.25062 }\end{array}$} \\
\hline
\end{tabular}

\section{INTRODUCTION}

In the present century, the world rapidly changing by being narrow, accessible, sharable, and familiar for all people as English is used as a common language apart from some variations in habits, cultures, traditions, regions, and idiosyncratic aspects. Consequently, English has growing qualities - it has been recognised as the global language of thousands of different languages (Crystal, 2003; Graddol, 2006). Most of the native and non-native speakers of English use this language as a mode of communication in their business matters or organisations (Yildirim \& Seker, 2004). Indisputably, English is so extensively used and so firmly established as a dominant global language, and its supremacy has become like a snowball that is too big to resist.

In the Indonesian context, the current status of English as a foreign language is focused on its common usage in a number of areas such as politics, diplomacy, international trade and industry, commerce, science and technology, and education

\footnotetext{
* Corresponding Author

Email: setyarini.english@upi.edu
} 
(Crystal, 2003; Jenkins, 2003). This status is commonly referred as a social agency of English which drives parents to provide better English proficiency to their children (Abedi, 2004) Correspondingly, owners of educational institutions, particularly private primary schools, consider English as an added value to school enrollment (Suwanto, 2017) as a means of educational internalisation (Adriani, 2018). However, this high demand and interest in English for young learners do not seem to receive proper government justification. Due to a lack of school readiness and a fear that the teaching of English at the earlier level could threaten young learners' acquisition of Bahasa Indonesia as their national language, English subject for primary school is excluded from the current National Curriculum 2013.

Due to a variety of teachers' competencies and school readiness, the practice of English to young learners shows a range of interesting practices to identify. Within different school capacities, teachers have to design their curriculum, apply learning methods, and develop learning materials and assessment. Due to diverse school clusters (local, national, and independent/international), some schools strive to list English as a compulsory subject, others prefer this subject as local content, and others position it as an extracurricular subject (Suwanto, 2017). It leads to a discussion of interschool readiness which covers the readiness of Indonesian schools from those three categories in teaching English as a foreign language. It also deals with the strategies of the teachers in preparing the students to compete globally through mastery of language skills and futuristic mindset.

Moreover, the success of English for young learners relies on teachers (Kersten \& Rohde, 2013). In Indonesia, this role becomes more significant in the absence of government regulation on the status of English for primary schools. However, due to high demand but low school readiness, quality assurance for English teacher for primary schools is sometimes neglected, leading to less professional recruitment of English teachers (Zein, 2016a). To meet the high request for English, teachers with low competence and irrelevant educational background are sometimes recruited to teach English for young learners, falsely believing that teaching English for this age cohort is simple and less demanding. Within this condition, some schools have more readiness to implement this subject, while others may have not.

This study examines the social agency demand and inter-school readiness for teaching English to young learners in various clusters of primary schools in Indonesia. To provide a more comprehensive account, the study explores different practices of English learning and teaching in three school clusters; local, national and independent by focusing on linguistic aspect learning materials and strategies, assessment and evaluation. It also identifies challenges and suggestions for teachers, so that they can improve the process of English teaching and learning for young learners to have better English language skills necessary for their future life.

\section{METHOD \\ Research design}

This study is triennial longitudinal research with different goals set in every year. In the first year, this study aimed to capture the English teaching process conducted in the various category primary schools. The second year of follow-up research focuses on the development of an oral cycle-based learning model that was manifested in three child-friendly submodels, namely storytelling, singing English songs, and playing educational games. The results of the developed model would be tested on three selected schools as a case study, then extended to other schools in the same area. The results of this test provided input for the researchers to revise future research. However, this paper only reports the firstyear findings dealing with the portrayal of teaching English for elementary students including social agency demands and interschool readiness, the implementation of an oral cycle in EFL primary context, teachers' challenges and solutions offered.

\section{Research site and participants}

This study involved students of years 4-6 in six different schools (three schools in Banten province and three others in West Java province) and their six English teachers. Based on the provincial government regulation, these schools are categorised into three different clusters, local (schools with limited standards and facilities below national standard), national (schools with facilities meeting the standards required by the national government), and international or now called independent (schools with national standards plus international curriculum). In this research, each cluster is represented by two primary schools from both provinces. The two local schools are located in remote areas, whereas the two international/independent schools are franchised institutions. In term of the students' number, the local schools had more students compared to the other two clusters. In detail, the local schools in two provinces consist of 35 students, the national clusters have 25 students, and the international ones have 15 students.

\section{Data collection techniques}

Data for this study were generated from classroom observations, interviews and document analysis conducted between July-November 2017. Observations were conducted in six participating classrooms, 60-70 minutes for each observation, conducted to identify detailed-classroom interactions, teaching methods, and process of English language teaching and learning. The observation was video recorded for a more thorough 
analysis and rich description of classroom interactions and learning methods. Meanwhile, interviews were conducted with six teachers and 12 students on the ELLT process added with analysis of teachers' lesson plans and classroom environments. These data were then classified into four aspects; language skills developed by teachers, learning materials, learning strategy, evaluation and assessment. Finally, these findings were triangulated to provide a convincing and reliable answer for each proposed research question.

For the convenience of participants in expressing their voices, interviews were conducted in Bahasa Indonesia, but transcripts were then translated into English. The translation is validated by authorised translator. For ethical reasons, participation in this study is voluntary so that participants were free to withdraw from the study when necessary. Consents from participating teachers, students and their parents were sought prior to data collection. All people and sites used in this study are pseudonyms.

\section{Data analysis}

The collected data from the three instruments were presented based on the topic of the study. The data from the classroom observation covering class interaction between the teachers and the students or the students and the students were transcribed and analysed by referring to the theory of classroom discourse analysis proposed by (Newton, 2002). The framework of analysis consists of two major categories, namely teachers talk and students talk. Teachers talks cover tuning, connecting, monitoring, and directions, while students talk includes response, self-initiated, and queries (Newton, 2002). The analysis results provided the patterns of interaction between which indicated the dominance of the classroom interaction. It was very beneficial to be investigated because dominance would be related to power and authority (Burns, 2017).

The data from interviews with the teachers are transcribed and analysed by using content analysis methods proposed by Nuendorf (2017). It aimed to reveal information on how English was taught in elementary schools and the challenges faced by the teachers in the classrooms. Conversely, the interviews with students were analysed referring to the content analysis focused on their responses to learning English (either positive or negative responses). The content analysis procedure was done by following several stages, namely data transcription, codification, data reduction, and interpretation to related theories.

\section{FINDINGS AND DISCUSSION}

Social agency demands and interschool readiness Referring to data analysis results from the three instruments to collect the data; namely, classroom observation, interviews with the teachers and the students, and document analysis, it is found that those three clusters of the schools showed their recognition towards the position of English subject in their schools from different conditions. The local schools admitted their eagerness to offer English as an important and interesting subject in their school. In fact, it was not formally offered as a local content, but it was taught as an extracurricular program claimed by one of the local teachers-respondent in the following extract:

Although English was not offered as a local content subject, it is continually taught as an extracurricular program done twice a week. This school policy program was believed as one of the positive images from the parents to send their children in that school.

This condition was elaborated from the observation results, referring that the teachers of local schools demonstrated their eagerness to teach as an extracurricular subject. Comparing to the other two schools' clusters, international and national, the local schools displayed that through English program, it invited many parents to send their children to study in that school. Moreover, in the interview, the teacher of local schools claimed that English was chosen as one of favourite subjects in that school because the parents believed that the earlier their children learn English, they tended to catch up the lesson more easily and can use the language quickly as investigated in the following excerpt:

I chose that school because English was offered as one of the subjects, so my son can learn English earlier, and he can use it more easily

Different from the local schools in two provinces, high social agency demands came from International schools because the parents perceived that English would be one of learning medium for their children. So, they were exposed to their confidence to communicate in English through their learning activities. By doing so, they were motivated to be global citizens.

In contrast, the social agency demands in the national cluster, it was found from the observation that the teachers seemed to treat English like the other subjects meaning that there was no special intention coming from the students' parents and the policymakers. Therefore, they run English as scheduled without any offers from school extra activity conducted outside the school program. In other words, it is found that social agency portrayed the demands of the schools depending on the stakeholders supported by authority makers and the parents who can support English learning either in the form of financial and facilities supports or motivation.

Regarding the interschool readiness, it covers three aspects, namely stakeholders' supports, facilities, and teachers' qualification. In term of stakeholders, the results of data analysis showed that local schools got less supports from the stakeholders 
because English was given as the extracurricular program yet it was not considered as the main subject learned by the students, even some parents showed their doubts whether English would inherence Bahasa Indonesia as their mother tongue and national identity since they believed that children in such young age were easily influenced and interfered. Therefore, some parents kept worrying their children learned English culture, which is considered opposite to their national identity, as stated in the following excerpt:

Our young children tended to learn everything more quickly than the adults, and we're a little bit worried about the cultures of target language since it was different from the national identity. Many exposures surrounding already showed the bad impact of western cultures, such as fashion which is likely different to Indonesia norms and characters.

Besides those two levels (local and national clusters), international level schools perceived English as a high social agency demands because it could determine the students' perspectives and their cognitive development. Some students had gained some exposure to good communication in English which is elaborated by some support of understanding the target language. This learning quality convinces the parents to be optimistic with their children English learning outcomes. From this point of view, the parents, teachers, and school managers tended to show their pride because the schools could serve what the stakeholders expected to get, i.e. putting English as one of the school subjects which has an equal treatment as the other mean subjects: math, religions, Bahasa Indonesia, etc. This statement was recorded in the following extract:

Although I spend much money for school tuition for my children, I am happy because they can communicate in English and started to learn about western cultures. So, my daughter is ready to go international.

Taking a look at the readiness of those two schools, local and international levels, national levels seemed not to expose their readiness that can be seen from facilities and materials used in English learning. The teachers just used the textbook given by the government without any supplementary materials and media prepared by the teachers and schools. Therefore, the observation results indicated that English was taught as the teachers did because there was no monitoring and evaluating process from the principals and authority holders as well as the suggestions from the parents.

\section{THE IMPLEMENTATION OF ORAL CYCLE IN EFL PRIMARY CLASSROOM}

Based on the analysis results from the three instruments, it revealed that each schools' cluster treated English differently which can be seen from how oral cycle was implemented as suggested by the previous curriculum for elementary students in learning English. From the observation results, the oral cycle was implemented in the international school through the teacher-student interactions in English. Both of the students and the teachers conducted discussions, question and answer sessions, and oral feedback in English. It was running well because the students claimed that they were used to speak in English both at home and at school. They preferred to get oral activities than written ones. The following conversation presents an example of a question and answer session between the teacher and the student in one international school in Banten province:

\begin{tabular}{|c|c|c|}
\hline Teacher (T) & : & What time is it? \\
\hline Student (S1) & $:$ & $\begin{array}{l}\text { Five past six. Good. Next, what } \\
\text { time is it? }\end{array}$ \\
\hline S2 & : & Quarter....um...seven \\
\hline $\mathrm{T}$ & & $\begin{array}{l}\text { Quarter past seven. Good. What } \\
\text { time is it? }\end{array}$ \\
\hline S3 & & Five to six \\
\hline $\mathrm{T}$ & & Five to six. Good. What time is it? \\
\hline S4 & & Five past two. \\
\hline $\mathrm{T}$ & & $\begin{array}{l}\text { Five past two. Good. What time is } \\
\text { it? }\end{array}$ \\
\hline
\end{tabular}

Considering the implementation of Oral Cycle as a form of English learning in the national cluster schools, both the teachers and the students apply to learn in written and oral forms in a balanced manner. However, in oral learning, the teacher played a dominant role compared to the students. It was seen from the discussion activities in English where the students did not catch the instructions and questions given by the teachers. So, the teachers wrote the questions on the whiteboard and asked the students to take notes in their books. The results of the interview with the teachers supported this finding claiming that the students had limited English vocabulary, so it was difficult for them to speak English fluently. The following excerpt explains one of the teachers' opinion about the students' difficulties in speaking English:

I understand that my students are difficult to speak in English fluently. This is due to the limited vocabulary, and they do not understand what I am saying. Sometimes, I have to say it three times or even write the questions on the board. It helps them a lot.

In addition, the teachers in the two local schools delivered oral routines like greetings and vocabulary development for lower classes 3-5 by asking students to memorise a list of words on specific topics from a textbook. To assist students' comprehension, the teachers sometimes use Bahasa Indonesia (L1) in their routines. It aims to enable participating students to understand the learning materials more comprehensively while maintaining Bahasa Indonesia as their national identity (Crawford, 2004; 
Inbar-Lourie, 2010; Levine, 2003). Some teachers from the local schools admitted that so far, they lacked confidence in speaking English due to their limited knowledge of grammar as seen in the following extract:

Frankly speaking, I don't really understand English grammar. It doubts me to speak in full English during teaching. I believe that if I make a mistake, then my students will do the same.

Within the limited speaking practice, the participating teachers prefer to emphasise on language structure in their teaching. Although the teacher in two local schools focused on oral vocabulary memorisation, the emphasis is on reading and writing, especially for year six. Similarly, listening and speaking skills practised by the national school cluster were then also followed by writing activities. Such a situation was also found in the national school cluster, which practised listening and speaking skills by focusing on grammar to improve students' writing skills. It implied that Indonesian teachers might believe that developing students' speaking skills is complicated to develop so that they focus more on reading and writing activities (Mohtar et al., 2015; Zhang, 2009).

The fact that most teachers do not have a good comprehension of the importance of oral language proficiency is evidenced by the content analysis results on the teaching documents. Lesson plans made by the teachers mostly focused on reading and writing, and little emphasis was given to the listening and speaking skill. The learning activities are written in the lesson plan, and the teachers put the reading and writing activities covered in the speaking activities. The teachers claimed that these skills basically had the same realisation in the classroom, and they did not need to select the strategy carefully as seen from the following extract:

I do not think that each skill has different strategies to be implemented in the classroom. Teaching speaking can be done through writing, reading, or listening. They all are the same.

The second aspect of teaching practice is teaching materials used by the teachers to implement oral cycle in three school clusters. Document analysis shows that the absence of government regulation leads to different learning materials. While the independent cluster uses internationally published textbook from Cambridge, local and national school clusters picked and chose their learning materials circulated by national publishers. The teachers in both local schools rely on a workbook since they were recommended by the school principals. However, this workbook has very poor quality both at content and print because it was printed black and white with low-quality paper and ink focusing on reading and grammar exercise, excluding oral proficiency at all. On the other side, the teachers at national schools have to make their own materials based on their students' needs but with poor content quality. This supports the fact that the majority of widely circulated English learning materials in Indonesia do not match the characteristics of primary school students (Suyanto, 2004), including poor illustrations and organisation (Basal et al., 2016).

In addition to workbooks, teachers also use some additional materials such as songs. A teacher of a local cluster uses the lyrics of Old McDonald to attract students' reading interests. Her students seemed to enjoy this learning via song. Another teacher in a national school cluster uses games by involving her students in word guess activity to develop vocabulary acquisition. These teachers assumed that English lyrics in a song and words in a game are interactive materials for students since they were encouraged to interact one to another with fun and attractive ways. One teacher of independent school cluster confirmed:

I usually use games and songs for my students. I think .... games are good for children in primary schools because they often play games at home. Besides games, I also use songs for children. They like it very much ... you know ... when we can sing together and learn new words, and they get fun.

To be more detailed, a comprehensive comparison of learning aspects in the three school clusters is summarised in Table 1.

Regarding the evaluation and assessment, the participating teachers use different types of assessment. First, local school teachers prefer to administer assessment by workbooks as school and homework activities which focus on reading and grammar with little emphasis on oral proficiency test through vocabulary memorisation. Assessment relies on reading; True and False, multiple-choice, and essay questions. Second, teachers of national school clusters similarly combine both oral and written tests plus homework of reading. Similar to the local school, homework which focuses on reading and writing is still the dominant mode of assessment at this cluster. Teachers also show a little emphasis on oral proficiency test of greetings and simple dialogues. Unlike those in the two school clusters, a teacher at an independent school in Bandung applies no homework policy and uses games as a formative assessment. This assessment is relatively innovative and relevant for millennial learners who are a digital native. This no homework policy is also a good phenomenon as it manages to reduce the emphasis on reading and writing skills, shifting to oral proficiency.

Again, similar to other previously discussed aspects of learning, assessment heavily emphasises on reading and writing. An exception applies to one independent school cluster which has no homework policy and a specific conversation class. Despite the elective status of English for young learners, most teachers do not make the best use of this flexibility for developing students' oral proficiency. They still 
focus their assessment on reading and writing like True and False, not oral proficiency, as if the students need to have government-based assessment like midsemester and end final examination.

Table 1

Comparison of English Teaching Practices in Three School-Clusters

\begin{tabular}{|c|c|c|c|c|}
\hline No & $\begin{array}{l}\text { Learning } \\
\text { aspects }\end{array}$ & $\begin{array}{l}\text { Cluster A } \\
\text { (Local Standard) }\end{array}$ & $\begin{array}{l}\text { Cluster B } \\
\text { (National Standard) }\end{array}$ & $\begin{array}{l}\text { Cluster C } \\
\text { (Independent Standard) }\end{array}$ \\
\hline 1. & $\begin{array}{l}\text { Language } \\
\text { skills }\end{array}$ & $\begin{array}{l}\text { Different skills between two } \\
\text { class groups: } \\
\text { Lower classes } 1-5 \text { focus on oral } \\
\text { language (vocabulary }\end{array}$ & $\begin{array}{l}\text { Focus on listening and } \\
\text { speaking, and then on writing } \\
\text { (grammar) }\end{array}$ & $\begin{array}{l}\text { Focuses on writing (grammar) } \\
\text { as the school also has a } \\
\text { conversation class which } \\
\text { focuses on oral skill. }\end{array}$ \\
\hline
\end{tabular}

Higher class 6 on writing

2. Learning

School recommended LKS (worksheet) with poor quality and teacher's own materials made from the life of students.

3. Learning Various strategies to avoid Strategy

students' boredom;

Song, video but focusing on

vocabulary memorisation and translation.

4. Assessment Oral in the form of vocabulary and memorisation and written

evaluation through workbook as homework.
No prescribed learning material from the government, so that teachers have to make their own based on their students' needs.

Songs and games designed by teachers.

Both oral and written skills sometimes through home works.
Internationally written text book (Cambridge) which is considered to accommodate students' and teachers' needs. No additional material is used.

Advance and competitive students need more diverse methods to avoid boredom; spelling bee and song.

No homework is given, only Formative assessment in the form of games.

\section{Some challenges and offered solutions}

Observations and interviews also identify some different challenges the participating teachers from each school cluster face in their English teaching practice. First, the absence of formal government regulation on English for young learners creates confusion, particularly for teachers in both local and national school clusters. As studied by Suwanto (2017), the exclusion of English from the Curriculum 2013 leads to three status; required subject, local content, and extracurricular. Despite this exclusion, the status of English in these two school clusters is local content, whereas at independent schools, it is still required. Second, most teachers have overload teaching hour of $30-40$ hours per week. The load is higher for teachers at local schools as each has only one English teacher. They need to teach all levels 46, within their parallel classes. This workload hampers them from having good preparation for their teaching and other professional development activities.

In addition, teachers at national cluster schools also have similar challenge. Beside overload teaching hours and large classes, due to its exclusion from the Curriculum 2013, teachers at local and national schools have to design their own learning materials and assessment. However, this challenge decreases because they can join a Focus Group Discussion (FGD) administered by local subject-teacher association, a platform to share challenges with other colleagues. Meanwhile, the challenge for teachers at independent schools is rather positive as they have to face advance, competitive and critical students who require more creative and challenging learning materials and teaching strategies. The students require teachers to be creative and innovative in designing learning materials due to their short attention spans. One teacher said,

I am lucky enough because ... um... my workload is not that big and the size my classrooms are small. However, my students are more like... demanding. Since this is an international school, students expect to have excellent English skills. So, um... I have to work harder. I have to design an interactive teaching method because, you know, my students get bored easily.

These challenges at three different school clusters are summarised in Table 2 .

It is bothersome to note that local schools do not seem to be ready to offer English but are forcefully market-driven. Despite minimum readiness, they manage to offer English to students either as local content or extracurricular activities. As previous studies have shown (Zein, 2016a, 2016b), most English teachers at this school cluster are of low competency. Despite a high commitment to teaching, they do not become relevant educational background in English education, low English proficiency, low competency in material development (Allington \& Johnston, 2002). Teachers at two higher clusters tend to have sufficient professionalism. However, since this local cluster school is the majority, failure of English teaching at this cluster may have a significant 
impact on the teaching of English to young learners in Indonesia. The teacher competency at this cluster should become the concern of both national and local government.

Based on these challenges, the study offers some solutions. First, teachers need to realise the importance of oral proficiency in learning English as a non-phonetic language in various activities such as TPR, mime, gestures, realia, and visual aids like maps, schedules, brochures, advertisements, and storybooks appropriate to learners' levels. Assessment should also be oral-based, with guided language use, focusing on communicative effectiveness, fluency over the accuracy, task-based oriented, with no error correction, dialogue and monologue, retelling stories, answering open-ended questions, giving explanations, describing, recalling, reporting events and processes and defining words (Snow, 1989).

Table 2

Challenges in Teaching English for Young Learners and their Solutions

\begin{tabular}{|c|c|c|c|}
\hline School clusters & Local & National & Independent \\
\hline $\begin{array}{l}\text { Some challenges } \\
\text { identified }\end{array}$ & $\begin{array}{l}\checkmark \text { High teaching load, one } \\
\text { teacher for the whole } \\
\text { school, } \\
\checkmark \text { No designated learning } \\
\text { materials that the teacher } \\
\text { needs to design his or her } \\
\text { own learning materials. } \\
\checkmark \text { High student-teacher ratio. }\end{array}$ & $\begin{array}{l}\checkmark \text { No prescribed learning } \\
\text { materials from the school } \\
\text { or department of education, } \\
\checkmark \quad \text { Semester assessment is } \\
\text { designed by local teacher } \\
\text { association, } \\
\checkmark \quad \text { The student-teacher ratio is } \\
\text { still high. }\end{array}$ & $\begin{array}{l}\checkmark \text { Advance, competitive and } \\
\text { critical students challenge } \\
\text { teachers to create more } \\
\text { creative and challenging } \\
\text { learning materials. } \\
\checkmark \text { Teachers need to be more } \\
\text { creative and competitive. }\end{array}$ \\
\hline $\begin{array}{l}\text { Solutions offered } \\
\text { by researchers }\end{array}$ & $\begin{array}{l}\text { Schools assist teachers with } \\
\text { learning materials; the ratio of } \\
\text { students-teachers be reviewed } \\
\text { for a better learning process. }\end{array}$ & $\begin{array}{l}\text { Teachers are involved in } \\
\text { training and seminar on } \\
\text { language learning; the } \\
\text { education department should } \\
\text { provide assessment materials? }\end{array}$ & $\begin{array}{l}\text { Teachers are more exposed to } \\
\text { various learning and teaching } \\
\text { strategies to improve students' } \\
\text { interest and motivation. }\end{array}$ \\
\hline
\end{tabular}

Second, to improve learning quality, it is important that local school principals assist the teachers with the provision of learning materials focusing on oral proficiency development. To enable more effective learning, schools should also hire more teachers so that student-teacher ratio becomes smaller. Third, as suggested by Zein (2016a, 2016b), teachers in all school clusters need to keep improving their professionalism by joining in-service professional development offered by the department of education or other organising committees, including benchmarking program to learn the best practices of English language teaching at other schools

\section{CONCLUSIONS}

Based on the aforementioned discussion, this study comes with some conclusions. First, within its limbo status, the practice of English teaching to young learners varies from one school cluster to the others. International and national schools tend to have better practices of English teaching by introducing more fun and interactive learning activities as well as interesting learning materials. However, they still have less emphasis on oral English proficiency. Meanwhile, most local schools still heavily emphasise reading and writing activities, with very minimum emphasis on oral proficiency. Within reading skill, grammar is still the focus of discussion. Next, supported by parents as a social agency, young learners prefer to have more communicative and functional English for their communication purposes.
Parents want their children to develop their oral proficiency as a strong indicator of English language competence necessary for their children future education. Third, teachers at local school cluster, the largest number in the country, have the poorest competence, thus need special attention. Instead of improving learners' English competence; misleading teaching practice by these mismatch teachers may even jeopardise the acquisition of English among young Indonesian learners.

This study also has a few limitations, particularly related to participant size. The number of participating schools is limited so that findings may not be generalisable to all primary schools in Indonesia. However, a rich description of triangulated observations, interviews, and document analysis provides robust justification to portray the real condition of English teaching for young Indonesian learners in three different school clusters. Second, although short-term observations may not cover overall teaching and learning practices at schools, cross-sectional data collection and triangulation may compensate for this limited duration.

\section{ACKNOWLEDGEMENT}

Thank you very much to the Ministry of Research, Technology, and Higher Education of the Republic of Indonesia who gave financial contribution in conducting this research. Our thankfulness comes to Universitas Pendidikan Indonesia for great supports to conduct the research. 


\section{REFERENCES}

Abedi, J. (2004). The No Child Left Behind Act and English language learners: Assessment and accountability issues. Educational Researcher, 33(1), 4-14. https://doi.org/10.3102\%2F0013189X0330010 04

Adriany, V. (2018). The internationalisation of early childhood education: Case study from selected kindergartens in Bandung, Indonesia. Policy Futures in Education, 16(1), 92-107. https://doi.org/10.1177\%2F147821031774539 9

Allington, R. L., \& Johnston, P. H. (2002). Reading to learn: Lessons from exemplary 4th-grade classrooms. Guildford.

Basal, A., Celen, K. M., Kaya, H., \& Bogaz, S. N. (2016). An investigation into illustrations in English course books in a Turkish context. International Electronic Journal of Elementary Education, 8(3), 525-536. https://files.eric.ed.gov/fulltext/EJ1096534.pdf

Burns, A. (2017). Classroom English proficiency: What can be learned from the Vietnam experience? In D. Freeman \& L. LeDrean (Eds.), Developing classroom English competence: Learning from the Vietnam experience (pp. 84-94). IDP Australia.

Crawford, J. (2004). Language choices in the foreign language classroom: Target language or the learners' first language? RELC Journal, 35(1), 5-20. https://doi.org/10.1177\%2F003368820403500 103

Crystal, D. (2003). English as a global language. Cambridge University Press.

Graddol, D. (2006). English next. British Council.

Inbar-Lourie, O. (2010). English only? The linguistic choices of teachers of young EFL learners. International Journal of Bilingualism, 14(3), 351-367. https://doi.org/10.1177\%2F136700691036784 9

Jenkins, J. (2003). World Englishes. Routledge.

Kersten, K., \& Rohde, A. (2013). Teaching English to young learners. In A. F. Mattsson \& C. Norrby (Eds.), Language acquisition and use in multilingual contexts: Theory and practice (pp. 107-121). Lund University.

Levine, G. (2003). Student and instructor beliefs and attitudes about target language use, first language use, and anxiety: Report of a questionnaire study. Modern Language Journal, 87(3), 343-364. https://doi.org/10.1111/1540-4781.00194

Mohtar, T. M. T., Singh, C. K. S., Abdullah, N. Y., \& Mat, M. (2015). Developing the speaking skill among ESL elementary learners. The Asian Journal of English Language \& Pedagogy, 3, 161-180. http://ojs.upsi.edu.my/index.php/AJELP/article /view/1226

Newton, P. (2002). Talking sense in science: Helping children understand through talk. Routledge.

Nuendorf, K. A. (2017). The content analysis guidebook. Sage.

Snow, R. (1989). Aptitude-treatment interaction as framework for research on individual differences in psychotheraphy. Journal of Consulting and Clinical Psychology, 59(2), 205-216. https://doi.org/10.1037/0022006X.59.2.205

Suwanto, S. (2017). The implementation and challenges of teaching English to young learners at primary schools in Bandung [Unpublished master's thesis]. Universitas Pendidikan Indonesia.

Suyanto, K. K. E. (2004, March 23). Pengajaran bahasa Inggris di sekolah dasar: Kebijakan, implementasi, dan kenyataan. Perpustakaan Digital Universitas Negeri Malang. http://library.um.ac.id/index.php/PidatoPengukuhan-Guru-Besar/pidato-gurubesar.html

Yildirim, R., \& Seker, M. (Eds.). (2004) Proceedings of the $1^{\text {st }}$ introduction language learning conference. Universiti Sains.

Zein, M. S. (2016a). Factors affecting the professional development of elementary English teachers. Professional Development in Education, 42(3), 423-440. https://doi.org/10.1080/19415257.2015.100524 3

Zein, M. S. (2016b). Pre-service education for primary school English teachers in Indonesia: Policy implications. Asia Pacific Journal of Education, 36(1), 119-134. https://doi.org/10.1080/02188791.2014.961899

Zhang, S. (2009). The role of input, interaction, and output in the development of oral fluency. English Language Teaching, 2(4), 91-100. https://doi.org/10.5539/elt.v2n4p91 